\title{
Law as a Sword, Law as a Shield
}

Politically Liberal Lawyers and the Rule of Law in China

Sida Liu, Ching-Fang Hsu and Terence C. Halliday

\section{OpenEdition \\ Journals}

\section{Electronic version}

URL: http://journals.openedition.org/chinaperspectives/8798

DOI: 10.4000/chinaperspectives.8798

ISSN: 1996-4617

\section{Publisher}

Centre d'étude français sur la Chine contemporaine

\section{Printed version}

Date of publication: 20 March 2019

Number of pages: 65-73

ISSN: 2070-3449

Electronic reference

Sida Liu, Ching-Fang Hsu and Terence C. Halliday, "Law as a Sword, Law as a Shield », China Perspectives [Online], 2019-1 | 2019, Online since 19 March 2020, connection on 22 December 2020 URL : http://journals.openedition.org/chinaperspectives/8798; DOI : https://doi.org/10.4000/ chinaperspectives.8798 


\title{
Law as a Sword, Law as a Shield
}

\author{
Politically Liberal Lawyers and the Rule of Law in China
}

\author{
SIDA LIU, CHING-FANG HSU, AND TERENCE C. HALLIDAY
}

\begin{abstract}
What does the rule of law mean in the Chinese context? Based on empirical research in Beijing and Hong Kong, this article examines the various ways politically liberal lawyers in China make sense of the rule of law in their discourses and collective action. Although the rule of law is frequently invoked by lawyers as a legitimating discourse against the authoritarian state, its use in practice is primarily for instrumental purposes, as both a sword and a shield. For activist lawyers in Beijing, the pursuit of judicial independence is nothing but a distant dream involving a restructuring of the state, and they therefore focus their mobilisation for the rule of law around basic legal freedoms and the growth of civil society. By contrast, Hong Kong lawyers hold the autonomy of their judiciary as a paramount value mainly because it is a powerful defensive weapon against Beijing's political influence. The rule of law as a shield is only effective where its institutional and normative foundations are solid (as in Hong Kong), and it becomes little more than a blunt sword for lawyers where such foundations are weak or missing (as in mainland China).
\end{abstract}

KEYWORDS: Rule of law, authoritarianism, political liberalism, lawyer, China, Hong Kong.

\section{Introduction}

A uthoritarianism is on the rise in China. So is the struggle for political change. As Xi Jinping consolidates his power and control over Chinese politics and society following his ascendance to leadership in 2012, law and lawyers have risen to the spotlight. On the one hand, the Fourth Plenary Session of the Eighteenth Congress of the Chinese Communist Party (CCP) in 2014 laid out a comprehensive blueprint for China's legal reform, characterised by more hierarchical control over the courts, more transparency of judicial decisions, as well as higher educational standards for entry into the legal profession and other legal careers. In March 2018, the CCP announced that it would establish a "Committee on Comprehensive Law-Based Governance" (Zhongyang quanmian yifa zhiguo weiyuanhui 中央全面依法治国委员会). On the other hand, the establishment of the National Supervision Commission has legalised the CCP's disciplinary system on its members and has created an alternative process for criminal sanctions (Li 2016), while the large-scale "709 Crackdown" on activist lawyers since July 2015 has sent a lasting chill over the entire Chinese legal profession (Liu and Halliday 2016; Fu 2018).

With these parallel and contorted developments, the meaning of rule of law in the Chinese context appears vague and elusive, despite the scholarly effort to situate it within China's political regime (Wang 2014; Li 2015; Trevaskes 2017). In this article, we approach the difficult topic of China and the rule of law from a unique perspective, that is, by examining how politically liberal lawyers in Beijing and Hong Kong make sense of the rule of law as it relates to authoritarianism and political liberalism. We find that rule of law is evoked as a discursive instrument to legitimise lawyers' fight against the authoritarian state. Law is a weapon with symbolic power, but alone it is insufficiently transformative in authoritarian contexts. In Beijing, it is used as a sword to advance lawyers' liberal pursuit; yet in Hong Kong, it is used as a shield to defend lawyers' commitment to judicial autonomy (Mosher and Poon 2009). Only by situating the rule-of-law discourses in lawyers' local fights against authoritarianism can we fully understand its meanings and implications in the context of China's legal and political change.

Our empirical data come from two separate yet complementary sources. First, from 2010 to 2015, Halliday and Liu repeatedly interviewed a group of activist lawyers in Beijing and discussed with them various aspects of the rule of law and political liberalism in detail. (1) With the assistance of an activist lawyer who served as his interpreter, Halliday also participated in some of their meetings and social activities as an unobtrusive observer. Many of our interviewees were persecuted during the 709 Crackdown, in which more than 200 lawyers were taken in for questioning or detained, and some suffered torture and imprisonment (Fu 2018). This development made our interview data an invaluable source for understanding the political values and ideology of Chinese lawyers in the prime of their careers as political activists.

Second, from 2016 to 2018, Hsu conducted interviews and participant observation with pro-democracy lawyers (2) in Hong Kong, including both barristers and solicitors. In 2016 and 2017, she approached her interviewees through a network of pro-democracy lawyers who aligned during the Umbrella Movement in 2014. The network, consisting of barristers, solicitors,

1. In the following text, interviews are coded in the format of "B1501," in which "B" refers to Beijing, and " 15 " refers to the year of the interview, while " 01 " refers to the number of the interview conducted in the year.

2. In this article, we identify the interviewees as "pro-democracy lawyers" but recognise the fact that they sometimes may identify themselves as "pan-democracy lawyers." In the mid-2000s, a number of political organisations emerged in Hong Kong, taking up different stances and proposing strategies to advance and consolidate democratic practices in the region. This created a spectrum of a pan-democracy camp, as opposed to the traditional group of pro-democracy advocates that first became active in the 1980s. For the purposes of analytical clarity and comparison with activist lawyers in Beijing, we adopt the term "pro-democracy" to refer to the Hong Kong lawyers discussed in the article. But note that these lawyers may not belong to the specific camp in the local context. We also emphasise that democracy and political liberalism cannot be conflated theoretically, although in the case of Hong Kong, pro-democracy lawyers are likely to be politically liberal as most of them support basic legal freedoms, civil society, and the moderate state (Halliday and Karpik 1997; Tam 2013; Lee 2017a, 2017b). 
law students, and some legally trained civil servants, has been active in local politics. They not only publish commentaries on public policies and legalpolitical issues but also organise formal and informal meetings to mobilise. While the network has a strictly anonymous policy to protect its members' identities, Hsu was invited to some private events and befriended several core members. In 2018, Hsu extended the scope of interviews to a wider range of Hong Kong lawyers, including solicitors in local and international law firms, and barristers who represent both individual and corporate clients. ${ }^{(3)}$ Hsu's interviews focused on lawyers' ideas of judicial autonomy in Hong Kong. For those politically active lawyers, the focus of inquiry was on their perceptions of, and thereafter resistance to, interventions from Beijing as the "one country, two systems" principle weakens in practice. For the less politically active lawyers, the focus of inquiry was on their views of and responses to the public discourse on rule of law. Reflections from routine practitioners in Hong Kong help us situate the pro-democracy lawyers in the broader legal community and identify the instrumentality of rule-oflaw discourse in the local context, in which an established common law system faces increasing pressure from an authoritarian regime.

Combining those two data sources therefore enables us to sketch an intricate mosaic of the ways that lawyers inside and outside of Communist rule interpret and make use of ideas of rule of law. Although the case of Hong Kong may seem distant from the case of Beijing at first glance, lawyers' encounters with the authoritarian legality of the Chinese state (Gallagher 2017) in the two cases make an empirically fascinating and theoretically meaningful contrast, as our data analysis in the following pages demonstrates. While rule-of-law discourse permeates the daily language of the Hong Kong legal profession, in order to legitimise their political stance, pro-democracy lawyers usually calibrate the rhetorical focus with respect to different political events. Similarly, activist lawyers in Beijing choose their cases and public voices carefully in order to gain legitimacy both domestically and internationally. The universal, anti-authoritarian orientation of rule-of-law discourse offers them a critical source of legitimation, as it does for pro-democracy lawyers in Hong Kong. In other words, the common opponent of the Chinese state and the authoritarian legality that it promotes in both mainland China and Hong Kong makes rule of law an indispensable ideology and a useful rhetoric for politically liberal lawyers in both cases. By documenting and analysing their rule-of-law discourses, we hope to present a window through which scholarly discussions on China and the rule of law can be grounded empirically in the actions and words of lawyers.

Given the high political sensitivity of our fieldwork in both sites, especially Beijing, we have not only omitted all the names and identifying information of our interviewees in the following text as required by research ethics, but have also adopted an analytical rather than narrative way of story-telling to further protect their identities. We also refrain from discussing our fieldwork strategies in detail in order to avoid exposing them to the potential surveillance of the Chinese state, which could make such risky empirical research impossible in the future. Nevertheless, in the following pages we make extensive use of direct quotes from our interviews to give the readers a good sense of lawyers' original discourses in both cases.

\section{China and the rule of law: Seeing like lawyers}

The rule of law is arguably one of the most enigmatic concepts in the social sciences. After decades of theoretical debate and empirical investigation, its meaning remains controversial and its analytical usage incoherent (Hart 1958; Fuller 1964; Dworkin 1985; Allan 2001; Tamanaha 2004; Ohnesorge 2007; Ginsburg and Moustafa 2008; Rajah 2012; Hadfield and Weingast 2014; Cheesman 2015; Krygier 2016; Massoud 2016; Versteeg and Ginsburg 2016). However different, in most of its scholarly versions the rule of law demands that "people in positions of authority should exercise their power within a constraining framework," rather than in "an arbitrary, ad hoc, or purely discretionary manner on the basis of their own preferences or ideology" (Waldron 2016). Hence, empirical research on the rule of law aims to capture "the relationship between law and the exercise of power" and to observe the functions of law in "articulating, channeling, constraining and informing, rather than merely serving, such power exercise" (Krygier 2012: 46). Subjecting the relationship between law and power to empirical rule-oflaw research, as we do in this article, is to capture a set of two-way interactions between political liberalism and authoritarianism. That is, we study politically liberal lawyers in China as agents in a difficult fight against arbitrary power, in which law is not only instrumental to their liberal pursuit but also serves as an effective tool for the authoritarian state to temper such effort. Informed by prior socio-legal studies on political liberalism, a concept developed for studying lawyers' political mobilisation across the world, we take its three main components into consideration: basic legal freedoms, civil society, and the moderate state (Halliday and Karpik 1997; Halliday, Karpik, and Feeley 2007; Halliday, Karpik, and Feeley 2012). In addition to the rule-of-law doctrine, which encompasses many elements of basic legal freedoms (e.g., legal proceduralism, due process, core civil rights, property rights, etc.) and the moderate state (judicial independence, fracturing of state power, etc.), the concept of political liberalism incorporates elements of civil society (professional associations, the public sphere, etc.) to capture the social forces that constrain the arbitrary exercise of power, which, in turn, speaks directly to the core of the rule-of-law debate.

The parallel lines of theoretical discussions on the rule of law, authoritarianism, and political liberalism can be integrated into three aspects of our empirical analysis: first, the procedural aspect of rule of law, which emphasises the modes of governance and often denotes that the government shall impose no penalty, stigma, or loss unless proper procedures are upheld (Tashima 2008); second, the substantive aspect of rule of law, which links formal features with individual liberty (Hayek 1960), equality (Allan 2001), and justice (Hart 2012), particularly manifested in the protection of fundamental human rights (Agrast, Botero, and Ponce 2011: 9) and property rights (Cass 2001); third, we examine lawyers' endeavours to strengthen civil society in order to fight against the authoritarian state. More specifically, we look into the bar (Halliday 1987), the legal complex, including (but not limited to) judges and lawyers (Karpik and Halliday 2011), and the connections between lawyers and other civil society groups.

This analytical framework allows us to reduce the ambiguity of rule of law as a concept, yet situates it in the local contexts of mainland China and Hong Kong. In the Chinese written language, there are two parallel concepts with the same pronunciation, fazhi, but one concept (法制) has a "knife" symbol in its character and the other (法治) has a "water" symbol. The second concept is often translated as "rule of law" and the first as "rule by law" in scholarly writings, but the official term frequently used by the CCP is "governing the nation in accordance with the law" or "law-based gover-

3. The interviews in Hong Kong are coded in a similar format of "HKS1701" or "HKB1701," in which "HK" refers to Hong Kong, " 17 " indicates the year of the interview, " $S$ " refers to solicitors while "B" refers to barristers, and " 01 " is the number of the interview conducted in that year. 
nance" (yifa zhiguo 依法治国). This peculiar term seems to conflate the German concept Rechtsstaat and the Anglo-American concept "rule of law," as the Chinese translation of Rechtsstaat would be "law-ruled state" (fazhi guo 法治国), almost identical to the CCP rhetoric of law-based governance. Conflating similar concepts is a common rhetorical strategy to disguise arbitrary power (Krygier 2006, 2012), as different generations of CCP officials continue to coin pseudo-legal terms denoting political goals. In the Jiang Zemin era, "law-based governance" was proposed as complementary to "morality-based governance" (yide zhiguo 以德治国), and then subsequently regarded as one of the three governing principles together with party leadership and the people's will in the Hu Jintao era (Li 2015; Wang and Liu 2019). Recently under Xi Jinping's leadership, "law-ruled China" (fazhi Zhongguo 法治中国) is one of the newly proposed terms. Meanwhile, the CCP's dominance over politics and society is made more explicit, which puts law-based governance in a subordinate position in the Chinese political and legal systems (Li 2015; Trevaskes 2017).

The subordination of law to power makes the practice of lawyers in China, especially political activists, full of tensions and pitfalls (Fu and Cullen 2008, 2011; Pils 2015; Liu and Halliday 2016; Stern 2017; Fu 2018). In our in-depth interviews with politically liberal lawyers in Beijing and Hong Kong, both legal proceduralism and substantive rights are frequently discussed but the primary target behind rule-of-law discourses is authoritarianism, as the Party-state sugar-coats unchecked political dominance with a legal façade. Similar to Cheesman's (2015) contrast between "law and order" and the rule of law in Myanmar, only by contrasting the rule of law with China's "authoritarian legality" (Gallagher 2017) can we grasp its localised meanings, manifested in the everyday struggles of politically liberal lawyers (Liu and Halliday 2011).

The juxtaposition of Hong Kong and Beijing lawyers sharpens this contrast between the rule of law and authoritarianism. In mainland China, the public sphere is a contentious yet highly constrained space (Lei 2018), and bar associations are under the direct control of the administrative state (McMorrow, Liu, and van Rooij 2017). By contrast, in Hong Kong there is a vibrant bar and a mature civil society, long existing but increasingly pressed by Beijing (Tam 2013; Jones 2015; Lee 2017a, 2017b). The Hong Kong judiciary also enjoys a high degree of judicial autonomy, whereas Chinese courts are deeply embedded in local governments and the Party's political-legal committees ( $\mathrm{Ng}$ and $\mathrm{He}$ 2017). Do the variations on judicial autonomy and civil society between Beijing and Hong Kong lead to different conceptions of rule of law for lawyers in the two jurisdictions? Or do their ideas of rule of law converge because of the common threat from the authoritarian state?

As our empirical analysis in the following pages suggests, while lawyers in both cases strongly emphasise the procedural aspect of rule of law, especially legal proceduralism and the institutions of judicial independence, activist lawyers in Beijing demonstrate notably more attention to substantive rights and closer affinity with civil society than pro-democracy lawyers in Hong Kong, whose insistence on defending the judiciary sometimes puts them at odds with other activists in civil society. Nevertheless, the idiom of rule of law provides a useful symbolic weapon for both groups to fight against authoritarianism. In the case of Beijing, it is a blunt sword for activist lawyers to arm themselves against the abuse of state power when they have little else to reply upon, as well as an ideal for an alternative legal-political order. In the case of Hong Kong, it is a solid shield for pro-democracy lawyers to guard against Beijing's political influence and to maintain an institutionalised legal order.

\section{Rule of law as a blunt sword: Activist lawyers in Beijing}

Activist lawyers in Beijing often live marginalised and fraught lives. Constantly under the threat of state repression, they nevertheless take on some of the most sensitive and risky cases across China. Not surprisingly, they have experienced serious violations of both the procedural and substantive rights of their clients and themselves. This is especially the case for lawyers focusing on human rights cases, but it is also common for other criminal defence lawyers and public interest lawyers who frequently challenge the authoritarian state in their work. In our extended interviews, elements of the rule-of-law ideal are frequently evoked to justify their actions and challenge the state repression that they face in everyday practice. To some extent, rule of law becomes a "weapon of the weak" (Scott 1985) for these marginalised yet courageous lawyers.

One of the most commonly observed rule-of-law discourses is about the lack of judicial independence in China. A leading human rights lawyer called Chinese judges both "dictators" in court and "puppets controlled by other powers" (B1401). The local authorities can influence judicial decisions, especially in politically sensitive cases, through the CCP's political-legal committee (PLC), a Party organ sitting above the police, the procuracy, and the court in China's political-legal system (Wang and Liu 2019). As another lawyer commented, "[t]he Party controls everything, leads everything, and there are lots of subdivisions in the Party, and the PLC is the subdivision controlling the judicial system" (B1319). Under this structure, "the PLC is the leader, the quintessential part" (B1112), and "the police chief has a higher title in the Party than the court president or the chief procurator" (B1313). Consequently, in criminal cases, the police and the PLC "are the faucet that can cut off the case before it gets to court" (B1112). When cases do get to court, "as long as there is a prosecution, there must be a sentence; and as long as there is an appeal, it must be declined" (B1005) in order to maintain the authority of the police and the procuracy.

The deficiency in judicial independence makes empty promises of many basic procedural rights of lawyers and citizens in the legal process, especially in politically sensitive cases. For example, an activist lawyer described his experience with the police and the court when representing Falun Gong practitioners as follows:

When we got there the police said we could not meet with the suspect. They were told by the leaders that no Falun Gong cases could have legal representation. (...) We told the police about the Criminal Procedure Law, the Lawyers Law, and the right to meet with the suspect. The police officer said, "There are so many laws [but] we only listen to our leaders. Don't talk to us about the law." So we went back in May, and this time the judge showed us a piece of paper and on it there were signatures of the criminal suspects and on the paper it said, "[d]ear leaders, we do not need lawyers to represent us in this case." They were real signatures, but we don't know how they got them to sign. (...) The third time we went there was a Sunday. They held the trial at the detention centre. When we were trying to get there the road was blocked one kilometre from the detention centre. (...) Until the trial was over we couldn't meet our client in person. (B1131)

What is remarkable about this and many other similar encounters between activist lawyers and the police or the court is not only how much 
difficulty the lawyers faced, but also how persistently they stuck to procedural rules in fighting for their clients' legal rights. A group of activist lawyers even labelled themselves "die-hard lawyers" (sike lüshi 死磕律师), which implies exhausting all legal means to fight against procedural violations in court and in the public domain. Participants of the die-hard lawyering movement in 2011-2015 included not only notable human rights activists, but also many progressive elites and grassroots activists who usually do not handle sensitive human rights cases but nevertheless care deeply about legal proceduralism and the abuse of state power (Liu and Halliday 2016). As an active participant of the movement explained:

We don't have rule of law currently. In such a context die-hard lawyers appear. Although we don't have rule of law, we have law. But the court does not implement the law. It seriously violates the rights of the defendant. More importantly it produces unjust verdicts. [Diehard] lawyers don't want to be window-dressing. We want to make a difference. (B1416)

Die-hard lawyering is both an attitude and a practice. As an attitude, it draws heavily on the instrumentality of law and attacks all forms of power abuse in the legal process as far as possible with the rule of law as a weapon. As a practice, it combines courtroom drama with a "surrounding gaze" (weiguan 围观) on social media, particularly Weibo (the Chinese equivalent of Twitter), to maximise the impact of collective action (Teng 2012). Beneath the strong performativity of their action is a firm belief in the significance of legal proceduralism for the practice of lawyers and the proper administration of justice. As one notable activist lawyer commented:

Chinese judges are used to not complying strictly with procedural rules, so it is easy to find loopholes in proceedings. (...) So we will fight for this right to do the whole process again. (B1514)

In the Chinese context, as in many other places, the pursuit of legal proceduralism is deeply entangled with striving for substantive rights and justice (Pereira 2005; Dyzenhaus 2010). To some extent, die-hard lawyers choose to fight hard for proceduralism precisely because their fight for substantive rights in the judicial process is a steep uphill battle. For cases involving human rights issues, lawyers often take on a case knowing that it is destined to be a lost battle. Nonetheless, when asked which legal rights are the most fundamental to the rule of law, in addition to due process protections most activist lawyers state unequivocally their advocacy of basic legal freedoms such as freedom of speech, freedom of association, and religious freedom.

Freedom of speech, as one lawyer put it, "is the basis for supervision and checks and balances of power" (B1131). For another lawyer, "only freedom of speech will reveal the truth to the public" (B1112). Christian lawyers, who accounted for a significant proportion of China's human rights lawyers, often linked freedom of speech to religious freedom. One lawyer regarded religious freedom as the most fundamental one because it is "the basic standard for a free human being to think and believe and to live autonomously and independently" (B1123). Another Christian lawyer argued that freedom of association and freedom of speech are derived from religious freedom, which is concerned with the "freedoms of your soul, your mind, your heart" (B1108). For this lawyer, defending religious freedom is not limited to helping other Christians:
As a Christian I defend other religious believers. So, just as I am a Han, I defend Tibetans. I want to show the world that doing justice means not [only] doing justice with your own group. (B1108)

In addition to its emphasis on basic legal freedoms, the rule of law is often associated with the security of property rights under legal rules. This association manifests frequently and explicitly in our conversations with activist lawyers in Beijing. As China urbanised rapidly in the early twenty-first century, rural land-taking and urban evictions became prominent social problems and sometimes led to major social unrest (Cai 2010; Ong 2014; O'Brien and Deng 2015). Not surprisingly, activist lawyers were often at the frontline in such cases, which made them fully appreciate the importance of property rights. While many lawyers acknowledged the improvement of China's property law on the books (B1126, B1132), they also lamented the law's poor implementation. As a lawyer who had years of experience with land-taking and eviction cases explained:

Although the law has changed, local governments just ignore it. They act like robbers. Sometimes the local governments hire mafia to fight with people and move them out. Since the law is not effective, lawyers are not effective, and we have no choice but to let the farmers fight their own battles against the government. (B1403)

Despite the great difficulty of protecting citizens' property rights in practice, some activist lawyers regarded it as closely related to "the dignity of human beings" (B1126, B1523). Furthermore, one lawyer even argued that protecting property rights would "change the relationship between citizens and the government" and "help with the development of democracy in China" (B1123). Although this argument remains a distant hope in the Chinese context, it shows how activist lawyers construct their system of beliefs by connecting different elements of the rule of law.

Yet there are two other interrelated discourses in our interviews with activist lawyers in Beijing that neither the procedural aspect nor the substantive aspect of rule of law captures directly: (1) the discourse of their fight against the authoritarian state; and (2) the discourse of the growth of civil society. Despite the shrinking space for civil society in China since Xi Jinping's ascendance to power (Fu and Distelhorst 2018), many activist lawyers considered their work closely associated with building a viable civil society, sometimes by "waking up rights consciousness of Chinese citizens" (B1113). The capacity of citizens to mobilise and engage in rights activism was often linked to the prospect of rule of law in China. As the following two lawyers commented:

There are two aspects [of rule of law]. First, the public must believe in and respect laws. Second, we have a very effective system of supervision that could enforce laws. (...) We also hear that there is no rule of law in China. (...) In China opposition political parties and the public have made no impact. So the responsibility of supervising the implementation of law falls on individual citizens. Only individual citizens can take on their responsibility to supervise illegal conduct. (B1120)

In the past I was interested in political movements. (...) Right now I am interested in religious freedom and freedom of speech. China will not change at all if China does not grant religious freedom and freedom 
of speech. I never believed that lawyers would be a major force in producing political reform in China. (...) We should not consider human rights lawyers in China as our saviours. Chinese society is not a rational society. The major force comes from ordinary citizens in China, and that will compel civil society and democracy in China. (B1106)

Note that both lawyers emphasised the importance of working with ordinary citizens to supervise law enforcement and build up the capacity of civil society. In their cases, some activist lawyers mobilised with petitioners, Christian house churches, labour NGOs, and other sectors of civil society, and that was a direct cause of the 709 Crackdown in July 2015 (Fu 2018).

One reason that activist lawyers reached out to citizens was that statecontrolled bar associations in China were not supportive of lawyers' collective action. Unlike common law jurisdictions in which bar autonomy and judicial autonomy are inseparable elements of the rule of law (e.g., Hong Kong, see next section), in China bar associations and the judiciary are two independent lines of professional regulation or, more accurately, two institutional channels of Party-state containment. As one leading activist lawyer puts it:

The Chinese government's concept of bar associations is that bar associations are embedded inside the executive power. I call the whole system Manchu-ism - a royal soldier [the justice bureau] and a fake royal soldier [the bar association]. (B1401)

The role of bar associations and justice bureaus is often "to restrict and oppress lawyers" (B1414). A human rights lawyer who was disbarred in 2009 discussed how this control worked in practice:

When the government wants you to back up on a case, the justice bureau will call the managing partner of the law firm and ask him to kick you out. Either you leave, or you stay and will not be allowed to do cases. If you leave and transfer your license, the justice bureau will prevent the transfer. So you are left hanging. (B1419)

Another activist lawyer whose license was taken by the Beijing Bureau of Justice despite his repeated demands for the justice bureau to hold a hearing and return his license also commented:

Only when they return my license can I demonstrate to the public that the justice bureau is a constitutional and legal institution. The justice bureau should not trample on the Constitution. (B1523)

The use of the Constitution in this quote to criticise the abuse of power in professional regulation is a striking example of how rule-of-law ideas are mobilised by Chinese activist lawyers in their fight against the authoritarian state. As another lawyer argued:

If there is a rule or regulation that is not consistent with a higher law, we should break that law and ask for change that is consistent with higher law. The highest law is China's Constitution. (B1112)

In the Chinese context, however, the Constitution is not subject to judicial review and thus cannot be applied directly in legal cases. Instead, the power of the Party-state penetrates the judicial process.
All the way from the Supreme People's Court to the local court, every court is under the leadership of the Party and must be loyal to the Party. So ultimately it is loyalty to a political leader. (B1306)

As a result:

All the good laws will be discounted in practice. But all the bad laws will be well implemented. (B1307)

The fight for rule of law naturally becomes a fight against the authoritarian state. Even the formalistic version of the rule of law requires government officials to follow the law (Raz 1979). Chinese activist lawyers' experiences with the authoritarian state point to two contrasting aspects of instrumentality of law in relation to power: (1) the authoritarian state uses law to facilitate arbitrary rule, that is, law serves power and its abuse by state officials; and (2) lawyers use law to bring power in line and protect the vulnerability of citizens and themselves against state repression. The second aspect is particularly intriguing, as lawyers use law as both a "weapon of the weak" (i.e., to be used by marginalised lawyers) and a "weapon for the weak" (i.e., to protect vulnerable citizens). In other words, law provides the possibility to at least partially re-equilibrate the imbalance of power between the strong state and weak individual citizens. And it is lawyers' task to twist this equilibrium against the state and towards citizens.

Yet Chinese activist lawyers differ in their views of how to achieve the equilibrium. Some advocate for incremental change through individual cases (B1103, B1114, B1132), whereas others call for more fundamental reform of the political and legal systems (B1104, B1131). As one notable activist lawyer commented:

My focus is not on defending the weakest. I believe that changing the law is more important than individual cases. If the law is changed, that will affect a large group of people. (B1104)

Yet some lawyers do not see any conflict between the two approaches:

Every case is a confrontation with the government. Each confrontation with the government is a protection or defence of the legal system or rule of law in China. Through individual cases again and again we are trying to tell the government that without democracy, without a new system, no one in your judicial system will execute the law. We want to tell the government, if your own people do not obey a law you have made, your party is headed toward a dead end. (B1111)

Despite lawyers' firm stance on the other side of authoritarianism, even incremental changes in individual cases are difficult to achieve. In our conversations, Chinese activist lawyers frequently referred to the government as a "police state" in which "the power of the police is unlimited" (B1317). According to a lawyer who was detained and tortured by the police repeatedly, the police officer told him the following while detaining him:

I am a police officer of the PRC and my job is to deal with people like you. In this place, whether we abide by the law or not is our choice. (...) We are more powerful than you. We can do anything, regardless of the law. (B1320) 
Most importantly, the police "point the gun at the enemies of the state, like Falun Gong, dissidents, or Christians" (B1323), all of whom are among the clients of activist lawyers.

Therefore, the law is also a weak weapon, a glorious yet powerless instrument for Chinese lawyers to use in their fight against authoritarianism. Consequently, many lawyers have resorted to the media, particularly the less censored social media, to expose abuse of power by the police and other state officials. For example, one lawyer mentioned that in most of his cases he had a "media strategy" because "without the involvement of the media it is impossible for the public to get to know the case and impossible for the public to get to know the legal problems" (B1005). Another lawyer emphasised the educational function of publicising their legal opinions to the media, as "the public will know how international standards apply, how other countries deal with similar cases" (B1104). However, with increased control and censorship over social media since the mid-2010s (Lei 2018), the effectiveness of such media strategies has also decreased, leaving activist lawyers limited options for making their voices heard by the Chinese public.

In short, for activist lawyers in Beijing, the rule of law is both an ideal and a weapon in their persistent fight against authoritarianism and for a more liberal-legal political society. Both procedural and substantive aspects of the rule of law are frequently invoked in their discourses, yet they are bounded by the structural constraints of both a highly repressive state and a nascent and oppressed civil society. As a result, rule of law becomes a shiny but blunt sword with more symbolic than substantive power. It is often ineffective in helping lawyers win legal battles in court, but by firmly sticking to it, activist lawyers can at least legitimise their words and actions before the state, the public, and the international community. Through rule of law they keep alive the consciousness and hope of a future political-legal order in a new China.

\section{Rule of law as a solid shield: Pro-democracy lawyers in Hong Kong}

In Hong Kong, the rule of law is also a weapon for lawyers to resist authoritarianism. However, while the mainland activist lawyers attempt to use rule of law to shift the power relations between the state and citizens, politically liberal lawyers in Hong Kong expect rule of law to shield the jurisdiction from authoritarian rule, as a defensive mechanism for preserving the current legal system and maintaining the power equilibrium in local politics. Often labelling themselves "pro-democracy lawyers" or "pandemocracy lawyers," these lawyers embrace not only universal suffrage but also civil society and judicial independence. Judicial autonomy is the core element of rule-of-law discourse for Hong Kong lawyers, which is constructed from three aspects: (1) organic legal doctrines embedded in the common law system; (2) an independent and professional judiciary; and (3) a united bar of integrity. All three aspects are frequently referred to in the context of resisting Beijing's external influence.

A British colony for more than a century before its handover to the People's Republic of China in 1997, Hong Kong has a common law system that was mostly kept intact when it returned to China. Maintaining the organic legal doctrines and the linkage to the common law world is a key insurance to keep the institutional design of "one country, two systems" - a political promise made by Beijing to delimit its own power in Hong Kong. This promise was clearly prescribed in Article 8 of the Basic Law of the Hong
Kong SAR: "The laws previously in force in Hong Kong, that is, the common law, rules of equity, ordinances, subordinate legislation and customary law shall be maintained."

Some Hong Kong lawyers refer to this legal continuity as a guarantee that Hong Kong would not fall to the authoritarian practices in the mainland (HKS1705), or that China would restrain itself from changing the status quo. For instance, the former chair of the Hong Kong Bar Association, Paul Shieh, demonstrated this point with his own life story. When he was about to begin his legal study at the University of Cambridge in 1983, he applied to transfer to natural science for the reason that Hong Kong's future was undecided. The school administration accepted his application, but he withdrew the transfer "based on one word, belief. I believed that [the mainland] would not greatly change Hong Kong but keep Hong Kong; you're not going to screw Hong Kong, not go backwards. So I chose to study law" (Lin 2017). Maintaining common law institutions is not only consistent with the political promises made by Beijing but also an organic operation that lawyers perform to sustain the power of the citizenry vis-à-vis the government. In September 2014, Hong Kong witnessed the Umbrella Movement, an unprecedented 81-day street demonstration in which more than a million residents participated to demand universal suffrage. Confrontation erupted between the police and protesters, resulting in many court cases concerned with the freedoms of speech and assembly. Hong Kong barristers mobilised to represent the Umbrella protesters (Lee 2017b). After losing one case of civil disobedience, a barrister who represented several defendants nevertheless expressed his unyielding confidence in Hong Kong's rule of law, "because we are connected to the common law. I might lose this time, but I'll use another argument next time, and I might win" (HKB1701). The organic and consistent embeddedness of Hong Kong jurisprudence in the common law world, in his opinion, provides lawyers like him with legal instruments and a fair chance to practice civic rights and check government power in court.

Judicial autonomy is the second aspect that reoccurs in comments by prodemocracy lawyers on the rule of law in Hong Kong. Theoretically, an independent and professional judiciary is a key institutional requirement of rule of law as well as an inherent element of political liberalism (Halliday and Karpik 1997; Ginsburg and Moustafa 2008). Empirically, the Hong Kong bench, which has maintained consistent competency and impartiality for generations, is often referred to as an instrument that resists the one-sided legal-political agenda pursued by the Hong Kong SAR government and Beijing. A politically active barrister who self-identified as a progressive explained the trusted role of the Hong Kong judiciary:

When you have an executive who is not accountable to the mass public and a legislature, at least most of them are not directly accountable to the people, and you have a judiciary, you can have more trust that they are not for the government. People see some cases ruling against the government, that the government doesn't always get its way; whereas in the legislature, the government almost always gets its way, and of course the executive is a government. So that's where the lawyers' trust [of the judiciary] comes from. The trust is relative. (HKB1702)

The perceived role of the judiciary, or expectations of politically liberal lawyers like him, is arguably a reason why many lawyers in Hong Kong have reacted strongly when Hong Kong government officials appear to under- 
mine the court. Since 1997, Hong Kong lawyers have initiated at least four public demonstrations, styled "dress in black, march in silence," to defend judicial independence (Tam 2013; Lee 2017b). Three out of the four demonstrations, respectively in 1999, 2005, and 2016, were in direct response to interpretations of the Basic Law by the Standing Committee of the National People's Congress (NPCSC) in Beijing, while one protest in 2014 was a reaction against the statement in the White Paper issued by the PRC State Council that judges, being part of the Hong Kong government, should be patriotic. An expatriate solicitor and former partner at a major American law firm shared his observation:

Rule of law to Hong Kong lawyers is judicial independence, as in they disapprove that judges should "love the country," and separation of powers, so when Zhang Xiaoming [the Director of the Liaison Office of the Central People's Government in Hong Kong] said the CE [the Chief Executive] overrides three organs and that separation of powers is not for Hong Kong, that's what people have taken issue with. (HKS1706)

Another solicitor, a self-identified "liberal," indicated a similar view, supporting local judicial autonomy and opposing Beijing undercutting the court. Her comments concern the disqualification controversies in 2016. In October 2016, a number of pro-democracy members-elect of the Hong Kong Legislative Council (LegCo) held props or said slogans to protest against Beijing during their oath-taking ceremonies. The Hong Kong government soon filed an application for judicial review to disqualify the members-elect on the allegation that they did not take the oath solemnly. The Chief Executive also stated that an interpretation from Beijing may be necessary. While the case was under appeal in the Hong Kong judiciary, Beijing reacted before the court reached a final decision. The NPCSC issued an interpretation of the Basic Law in November 2016, essentially forbidding members-elect from expressing political views when they take the oath. This solicitor strongly disapproved of the actions taken by both governments and the political message behind them:

What lawyers care the most [for] is, (...) autonomy, don't let other people decide your own business. For example, the Hong Kong Chief Executive shouldn't ask Beijing to interpret the Basic Law. (...) Another example that really worries me is the 2016 LegCo election, the process in which some members are unseated. CE [The Chief Executive] filed the application to the judiciary, and before the court reached a decision, the NPCSC intervened. What annoys me the most is, why the CE [Chief Executive] brought this up to Beijing?! It's obviously something we can deal with. (HKS1704)

It should be noted, however, that a counter-argument is also present among Hong Kong lawyers. Precisely on this incident of Basic Law interpretation, another solicitor perceived otherwise:

The Basic Law is the bridge connecting the Hong Kong common law and Chinese continental law. You can't say Hong Kong has no rule of law because the NPCSC issues an interpretation. (HKS1707)

While this solicitor ignored the political agenda indicated in the NPCSC interpretation, Lawrence Ma, a barrister who publicly identified himself with "love for country, love for Hong Kong" (Primrose 2018), took a strict proce- dural standpoint to defend the interpretation's conformity to rule of law: "Although the NPCSC might have certain political aims in mind to be achieved, nonetheless, there was never any arbitrary exercise of power that infringed the spirit of the rule of law principle" (Lee et al. 2017).

Essentially the two voices differ on the question of whom the law serves. For some, law affords a neutral and procedural channel through which external political power can and is entitled to exert influence on Hong Kong by circumventing the local judiciary. As long as political influence meets the minimum procedural requirement, the rule of law remains. In other words, power can delimit judicial autonomy without undermining rule of law, as long as the law stipulates a way to do so. It is precisely this line of argument that puts the Hong Kong legal profession at odds with more radical pro-democracy activists, some of whom criticise the constrained position of lawyers on the NPCSC interpretation and other contentious issues. The third theme that emerged in interviews with Hong Kong lawyers, especially barristers, is the emphasis they place on a bar that preserves its independence and integrity (Lee 2017a). A large number of judges were practicing barristers before being elevated to the bench in Hong Kong, as in many other common law jurisdictions. Accordingly, a strong sense of professional fraternity is discernible in some barristers' defence of judicial autonomy. As a barrister-politician explained:

First, it's a feeling, they're one of us. One day I [a barrister] might sit on that bench too. Second, in the Hong Kong legal profession, or any common law legal profession, many were master and pupil before. It's personal. If you trace the professional ancestry, that judge has a relationship with me. (HKB1703)

The rhetoric of a united bar legitimises pro-democracy lawyers' support of the judiciary as a viable channel to resist authoritarian rule, if not the only viable channel left available in Hong Kong. Commenting on the oathtaking controversies mentioned above, the barrister-politician defended the judiciary's decision following the NPCSC interpretation, which disqualified all six members-elect:

Everyone knows he [the judge] has his difficulties. Everyone is in the same boat. Facing the same authority, the same authoritarian regime. (...) if I attack him [the judge], he's left all alone. And the rule of law is the root of Hong Kong; the judiciary is one of the most important ingredients protecting the rule of law. (HKB1703)

It is evident from the quote that this barrister considered it a collective task for the bar, lawyers and judges alike, to shield the jurisdiction from authoritarian rule. A united legal profession serves this role via mutual support where the judiciary make judgments and lawyers produce public discourses to sustain the judiciary's legitimacy in the name of rule of law. Needless to say, there are many variations in attitudes towards Hong Kong's democratic movements vis-à-vis Beijing's influence among barristers and solicitors, yet the support of the judiciary and the common law system is mostly consensual across the bar and the solicitors' branches. Lawyers' insistence on defending the judiciary sometimes puts them at odds with other activists in civil society who are more critical towards the judiciary, especially when the court makes seemingly pro-Beijing decisions.

In sum, the rule of law is a solid but increasingly dented shield for prodemocracy lawyers to preserve the legal system and the way of life in Hong 
Kong from the encroachment of authoritarian rule across the border. Indeed for many Hong Kong lawyers, the rule of law is "a bordering practice" (HKS1706) to prevent retrogression to political arbitrariness. Judicial autonomy is the core element that centres many lawyers' discussions with three specific focuses on jurisprudence, the judiciary, and the bar, all of which are perceived to be instrumental in resistance to authoritarianism.

\section{Conclusion}

In terms of professional and social backgrounds, the two groups of lawyers in Beijing and Hong Kong on whom we have focused our discussion could not be more different. Most activist lawyers in Beijing came from humble social origins, did not have an elite legal education, and often migrated from the provinces to the capital (Liu, Liang, and Michelson 2014), whereas barristers and solicitors in Hong Kong are among the most globalised, cosmopolitan elite professionals in the world (Lee 2017a). Nevertheless, some of their views on the rule of law and its relationship to authoritarianism and political liberalism appear strikingly similar. Both groups emphasise the procedural aspect of rule of law, particularly the importance of judicial independence and legal proceduralism in resisting arbitrary state power. Furthermore, the rule of law is often "weaponised" as either a sword for political reform (for Beijing lawyers) or a shield against authoritarian attack (for Hong Kong lawyers). Echoing a recent study of how the Chinese state weaponises rule of law using official propaganda (Trevaskes 2017), our analysis in this article has shown that the instrumental use of rule-of-law discourse is also widespread among opponents of the state.

The comparison between Beijing and Hong Kong suggests that the fight for rule of law is highly sensitive to its local context. For activist lawyers

\section{References}

AGRAST, Mark, Juan BOTERO, and Alejandro PONCE. 2011. "World Justice Report Rule of Law Index 2011 Report." The World Justice Project. https://worldjusticeproject.org/our-work/publications/rule-law-index-reports/wjp-rule-law-index-2011-report (accessed on 13 February 2019).

ALLAN, Trevor R. S. 2001. Constitutional Justice: A Liberal Theory of the Rule of Law. Oxford: Oxford University Press.

CAl, Yongshun. 2010. Collective Resistance in China: Why Popular Protests Succeed or Fail. Stanford: Stanford University Press.

CASS, Ronald A. 2001. The Rule of Law in America. Baltimore: Johns Hopkins University Press.

CHEESMAN, Nick. 2015. Opposing the Rule of Law: How Myanmar's Courts Make Law and Order. Cambridge: Cambridge University Press.

DWORKIN, Ronald. 1985. "Political Judges and the Rule of Law." In Ronald Dworkin, A Matter of Principle. Cambridge: Harvard University Press. 9-32.

DYZENHAUS, David. 2010. Hard Cases in Wicked Legal Systems: Pathologies of Legality ( $2^{\text {nd }}$ ed.). Oxford: Oxford University Press.

FU, Diana, and Greg DISTELHORST. 2018. "Grassroots Participation and Repression under Hu Jintao and Xi Jinping." The China Journal 79: 100-22.

FU, Hualing. 2018. "The July $9^{\text {th }}$ (709) Crackdown on Human Rights Lawyers: Legal Advocacy in an Authoritarian State." Journal of Contemporary China 27: 554-68.

FU, Hualing, and Richard CULLEN. 2008. "Weiquan (Rights Protection) Lawyering in an Authoritarian State: Building a Culture of Public-Interest Lawyering." China Journal 59: 111-27. in Beijing, the pursuit of judicial independence is nothing but a distant dream involving a restructuring of the state under China's current political regime, and they therefore focus their mobilisation for rule of law around basic legal freedoms (e.g., freedom of speech and freedom of religion) and the growth of a nascent civil society. By contrast, Hong Kong lawyers hold the autonomy of their judiciary as a paramount value mainly because it is a powerful defensive weapon against Beijing's political influence. In other words, the rule of law as a shield is only effective where its institutional and normative foundations are solid (as in Hong Kong), and it becomes little more than a blunt sword for lawyers where such foundations are weak or missing (as in mainland China). Notably, in the Xi Jinping era, the sword of law remains blunt, and the shield of law is increasingly under attack.

\section{Sida Liu is Assistant Professor of Sociology and Law at the University of Toronto and Faculty Fellow at the American Bar Foundation.}

I Ching-Fang Hsu is Ph.D. Candidate in Political Science at the University of Toronto.

I Terence C. Halliday is Research Professor at the American Bar Foundation, Adjunct Professor of Sociology at Northwestern University, and Honorary Professor in the School of Regulation and Global Governance at Australia National University.

Please direct correspondence to Sida Liu, Department of Sociology, University of Toronto, 725 Spadina Avenue, Toronto, ON M5S 2J4, Canada (sd.liu@utoronto.ca).

Article received on 31 May 2018. Accepted on 12 February 2019.

FU, Hualing, and Richard CULLEN. 2011. "Climbing the Weiquan Ladder: A Radicalizing Process for Rights-Protection Lawyers." China Quarterly 205: 40-59.

FULLER, Lon. 1964. The Morality of Law. New Haven:Yale University Press.

GALLAGHER, Mary E. 2017. Authoritarian Legality in China: Law, Workers, and the State. Cambridge and New York: Cambridge University Press.

GINSBURG, Tom, and Tamir MOUSTAFA. 2008. "Introduction: The Functions of Courts in Authoritarian Politics." In Tom Ginsburg and Tamir Moustafa (eds.), Rule by Law: The Politics of Courts in Authoritarian Regimes. Cambridge and New York: Cambridge University Press. 1-22.

HADFIELD, Gillian K., and Barry WEINGAST. 2014. "Microfoundations of the Rule of Law." Annual Review of Political Science 17: 21-42.

HALLIDAY, Terence C. 1987. Beyond Monopoly: Lawyers, State Crises, and Professional Empowerment. Chicago: University of Chicago Press.

HALLIDAY, Terence C., and Lucien KARPIK. 1997. Lawyers and the Rise of Western Political Liberalism: Europe and North America from the Eighteenth to Twentieth Centuries. Oxford: Oxford University Press.

HALLIDAY, Terence C., Lucien KARPIK, and Malcolm M. FEELEY (eds.). 2012. Fates of Political Liberalism in the British Post-Colony: The Politics of the Legal Complex. Cambridge and New York: Cambridge University Press.

HALLIDAY, Terence C., Lucien KARPIK, and Malcolm M. FEELEY. 2007. "The Legal Complex in Struggles for Political Liberalism." InTerence C. Halliday, Lucien. Karpik, and Malcolm (eds.), Feeley Fighting for Political Freedom: Comparative Studies of the Legal Complex and Political Liberalism. Portland: Hart Publishing. 
HART, Herbert L.A. 1958. "Positivism and the Separation of Law and Morals." Harvard Law Review 71: 593-629.

HART, Herbert L.A. 2012. The Concept of Law ( $3^{\text {rd }}$ ed.). Oxford: Oxford University Press.

HAYEK, Friedrich A. Von. 1960. The Constitution of Liberty. Chicago: University of Chicago Press.

JONES, Carol A. G. 2015. Lost in China?: Law, Culture and Society in Post1997 Hong Kong. Cambridge: Cambridge University Press.

KARPIK, Lucien, and Terence C. HALLIDAY. 2011. "The Legal Complex." Annual Review of Law and Social Science 7: 217-36.

KRYGIER, Martin. 2006. "The Rule of Law: An Abuser's Guide." In András Sajó (ed.), Abuse: The Dark Side of Fundamental Rights. Utrecht: Eleven International Publishing.

KRYGIER, Martin. 2012. "Rule of Law and the Rechtsstaat." In Michael Rosenfeld and András Sajó (eds.), The Oxford Handbook of Comparative Constitutional Law. Oxford: Oxford University Press.

KRYGIER, Martin. 2016. "The Rule of Law: Pasts, Presents, and Two Possible Futures." Annual Review of Law and Social Science 12: 199-229.

LEE, Man Yee Karen. 2017a. "Beyond the 'Professional Project': The Political Positioning of Hong Kong Lawyers. " International Journal of Law, Crime, and Justice 50: 1-11.

LEE, Man Yee Karen. 2017b. "Lawyers and Hong Kong's Democracy Movement: From Electoral Politics to Civil Disobedience." Asian Journal of Political Science 25: 89-108.

LEE, Martin, Ronny TONG, Paul SHIEH, Priscilla LEUNG, and Lawrence MA. 2017. "How Healthy Is Hong Kong's Rule of Law? Five Legal Experts Weigh In." South China Morning Post, $1^{\text {st }}$ June 2017, sec. EDT7.

LEl, Ya-Wen. 2018. The Contentious Public Sphere: Law, Media, and Authoritarian Rule in China. Princeton: Princeton University Press.

LI, Ling. 2015. "'Rule of Law' in a Party-State: A Conceptual Interpretive Framework of the Constitutional Reality of China." Asian Journal of Law and Society 2: 93-113.

LI, Ling. 2016. "The Rise of the Discipline and Inspection Commission, 1927-2012: Anticorruption Investigation and Decision-Making in the Chinese Communist Party." Modern China 42: 447-82.

LIN, Li 林勵. 2017. “法治屢遭歪曲 石永泰:成個法律界忍咗好耐!” (Fazhi lü zao waiqu Shi Yongtai: cheng ge falü jie ren zuo hao nai, Rule of law is repeatedly distorted - Paul Shieh: the whole legal sector has been tolerating!). Citizen news, 20 June 2017. https://www.hkcnews.com/ article/4722/石永泰-法 (accessed on 12 February 2019).

LIU, Sida, and Terence C. HALLIDAY. 2011. "Political Liberalism and Political Embeddedness: Understanding Politics in the Work of Chinese Criminal Defense Lawyers." Law \& Society Review 45: 831-65.

LIU, Sida, and Terence C. HALLIDAY. 2016. Criminal Defense in China: The Politics of Lawyers at Work. Cambridge and New York: Cambridge University Press.

LIU, Sida, Lily LIANG, and Ethan MICHELSON. 2014. "Migration and Social Structure: The Spatial Mobility of Chinese Lawyers." Law \& Policy 36 165-94.

MASSOUD, Mark Fathi. 2016. "Ideals and Practices in the Rule of Law: An Essay on Legal Politics." Law \& Social Inquiry 41: 489-501.

MCMORROW, Judith, Sida LIU, and Benjamin VAN ROOIJ. 2017. "Lawyer Discipline in an Authoritarian Regime: Empirical Insights from Zhejiang Province, China." Georgetown Journal of Legal Ethics 30: 267-300.

MOSHER, Stacy, and Patrick POON (eds.). 2009. A Sword and a Shield: China's Human Rights Lawyers. Hong Kong: China Human Rights Lawyers Concern Group.
NG, Kwai Hang, and Xin HE. 2017. Embedded Courts: Judicial DecisionMaking in China. Cambridge: Cambridge University Press.

O'BRIEN, Kevin J., and Yanhua DENG. 2015. "Repression Backfires: Tactical Radicalization and Protest Spectacle in Rural China." Journal of Contemporary China 24: 457-70.

OHNESORGE, John, K.M. 2007. "The Rule of Law." Annual Review of Law and Social Science 3: 99-114.

ONG, Lynette H. 2014. "State-Led Urbanization in China: Skyscrapers, Land Revenue and 'Concentrated Villages'." China Quarterly 217: 162-79.

PEREIRA, Anthony W. 2005. Political (in) Justice: Authoritarianism and the Rule of Law in Brazil, Chile, and Argentina. Pittsburgh: University of Pittsburgh Press.

PILS, Eva. 2015. China's Human Rights Lawyers: Advocacy and Resistance. London: Routledge.

PRIMROSE, Riordan. 2018. "Australians Part of Beijing-Backing Body." The Australian, 9 January 2018. https://www.theaustralian.com.au/nationalaffairs/foreign-affairs/australians-part-of-beijingbacking-body/newsstory/4b2ea89f77dc59986acbdeb26075a816 (accessed on 12 February 2019).

RAJAH, Jothie. 2012. Authoritarian Rule of Law: Legislation, Discourse, and Legitimacy in Singapore. Cambridge and New York: Cambridge University Press.

RAZ, Joseph. 1979. "The Rule of Law and Its Virtue." In Joseph Raz, Authority of Law: Essays on Law and Morality. Oxford and New York: Oxford University Press. 210-29.

SCOTT, James. 1985. Weapons of the Weak: Everyday Forms of Peasant Resistance. New Haven: Yale University Press.

STERN, Rachel E. 2017. "Activist Lawyers in Post-Tiananmen China." Law \& Social Inquiry 42: 234-51.

TAM, Waikeung. 2013. Legal Mobilization under Authoritarianism: The Case of Post-Colonial Hong Kong. Cambridge: Cambridge University Press.

TAMANAHA, Brian Z. 2004. On the Rule of Law: History, Politics, Theory. Cambridge and New York: Cambridge University Press.

TASHIMA, A. Wallace. 2008. "The War of Terror and the Rule of Law." Asian American Law Journal 15: 245-66.

TENG, Biao. 2012. "Rights Defence (Weiquan), Microblogs (Weibo), and the Surrounding Gaze (Weiguan): The Rights Defence Movement Online and Offline." China Perspectives 2012(3): 29-41.

TREVASKES, Susan. 2017. "Weaponising the Rule of Law in China." In Flora Sapio, Susan Trevaskes, Sarah Biddulph, and Elisa Nesossi (eds.), Justice: The China Experience. Cambridge: Cambridge University Press. 113-40.

VERSTEEG, Mila, and Tom GINSBURG. 2016. "Measuring the Rule of Law: A Comparison of Indicators." Law \& Social Inquiry 42: 100-37.

WALDRON, Jeremy. 2016. "The Rule of Law." In Edward N. Zalta (ed.), The Stanford Encyclopedia of Philosophy. Stanford: Stanford University. https://plato.stanford.edu/entries/rule-of-law/ (accessed on 12 February 2019).

WANG, Juan, and Sida LIU. 2019. "Ordering Power under the Party: A Relational Approach to Law and Politics in China." Asian Journal of Law and Society (forthcoming).

WANG, Yuhua. 2014. Tying the Autocrat's Hands: The Rise of the Rule of Law in China. Cambridge and New York: Cambridge University Press. 